\title{
Wührl Tibor
}

\section{Drónkommunikáció: I-Q-moduláció hatékony megvalósítása DSP-vel}

Drónokat számos területen használunk. Csaknem minden felhasználási terület igényli, hogy a drónok információkat fogadjanak vagy továbbítsanak akár egy másik drónnak, vagy a földi szegmensnek. Az analóg átviteli csatornán a digitális jelekkel leírt információt digitális modulációs eljárásokkal tudjuk továbbítani.

Ebben a cikkben egy hatékony, többszintü digitális modulátor megvalósíthatóságát mutatom be, amely kis teljesítményü, fix pontos számábrázolást használó jelfeldolgozó processzorral megvalósitható. A bemutatott DSP-algoritmus analóg I-Q-jelet állít elö, amely analóg AM-DSB/ SC-eljárással kisugározható rádiófrekvenciás jellé konvertálható.

Kulcsszavak: drón, kommunikáció, I-Q-modulátor, DSP

\section{Bevezetés}

A jó minőséget biztosító digitális kommunikációs csatorna meghatározója egy drónrendszer jóságának, sikeres használhatóságának. Napjainkban a drónokra különféle küldetéseket bízunk, és a jövőben egyre többfélét bízni fogunk. A drónok katonai, katasztrófavédelmi, üzleti felhasználhatósága már nem képezi vita tárgyát, és a közeljövőben a hétköznapi életünk részévé is válik a felhasználásuk [1], [2], [4]. Sokan hobbicéllal alkalmazzák ezen eszközöket.

Bármely felhasználást vizsgáljuk is, azt állapíthatjuk meg, hogy a küldetésre indított drónok valós időben vagy kvázi valós időben információt juttatnak a földi szegmens felé (például fedélzeti információk vagy fedélzeten elhelyezett kamera, kamerarendszer által készített vizuális információk [1]). Kötelékben repülő pilóta nélküli eszközök (például drónrajok) esetén a drónok folyamatosan megosztják a kötelék tagjaival a helyzetüket, esetleg ütközés elkerülése érdekében más repülőeszközöknek szolgáltatnak információt [3].

Ebben a cikkben egy digitális moduláció gyakorlati kialakítási módszereit mutatom be. Fontos törekvés, hogy a megvalósítás kis teljesítményü jelfeldolgozó processzorral vagy úgynevezett Signal Controllerrel (DSC) kivitelezhető legyen, mivel egy kisméretű drón fedélzetére helyezhető tömeg jelentősen limitált. Fontos szempont továbbá a jó minőségü digitális csatorna (például jó bithibaarány) kialakításon túl az, hogy az egyes felhasználási igényektől függően az átviteli mód viszonylag rugalmasan átprogramozható legyen. 
Digitális átviteli csatorna kialakítása úgynevezett digitális modulációs eljárással történhet. Ez esetben a vivő jelet egy analóg, harmonikus jel jelenti, amelynek feszültség időfüggvénye:

$$
\mathrm{u}_{\text {vivŏ }}(\mathrm{t})=\hat{\mathrm{U}} \cdot \cos \left(\omega_{\mathrm{v}} \mathrm{t}+\varphi\right)
$$

A moduláció során a vivő jel valamely fizikai paraméterét változtatjuk meg, és ez a változás fogja hordozni az információt, vagyis a digitális jelfolyamot. Az amplitúdó megváltoztatása esetén ASK-, a frekvencia megváltoztatása esetén FSK-, míg a fázishelyzet megváltoztatása esetén PSK-eljárásról beszélünk. Abban az esetben, ha a vivő amplitúdó és fázishelyzet együttesen hordoznak információt, akkor digitális QAM-röl beszélünk.

\section{Elméleti alapok, I-Q-sík leképzése}

Az elméleti alapok az analóg AM-DSB/SC-modulációig nyúlnak vissza. Szorzómodulációval végzett spektrumáthelyezés eredménye egy elnyomott vivőjü, dupla oldalsávos spektrumképet mutató amplitúdómodulált jel.

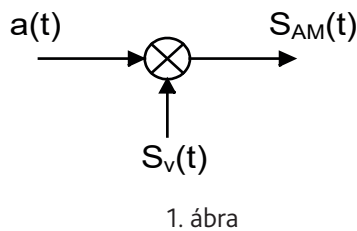

Szorzómodulátor elvi kialakitása [saját szerkesztés]

A fenti ábrán kialakított modulátor müködését a következő összefüggés írja le:

$$
\mathrm{S}_{\mathrm{AM}}(\mathrm{t})=\mathrm{a}(\mathrm{t}) \cdot \cos \left(\omega_{\mathrm{v}} \mathrm{t}\right)
$$

Az összefüggésben a(t) a moduláló jel, valamint a vivőjel egységnyi amplitúdójú, $0^{\circ}$ kezdőfázisú koszinuszos jel. A komplex forgó vektoros modellel [10] leírt vivőjel:

$$
S_{V}(t)=\cos \left(\omega_{v} t\right)=\frac{1}{2} \cdot e^{j \omega_{V} \cdot t}+\frac{1}{2} \cdot e^{-j \omega_{V} \cdot t}
$$

A vivőjel spektrumképének abszolút értéke a modell szerint:

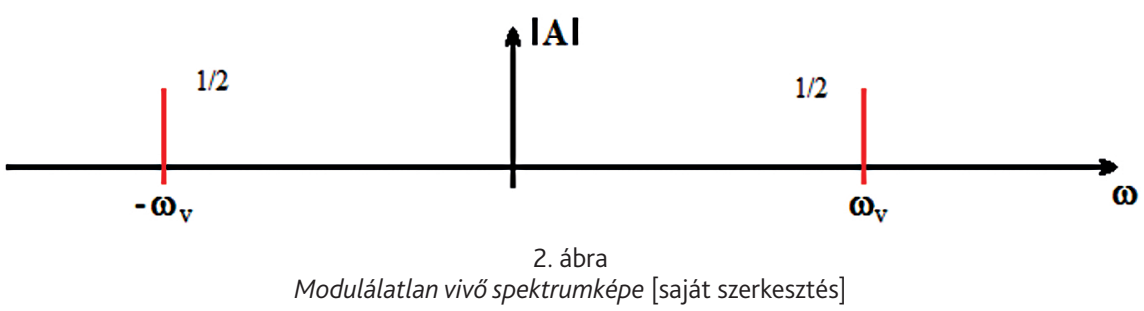


Az AM-DSB/SC-jel az időtartományban vizsgálva pedig:

$$
\mathrm{S}_{\mathrm{AM}}(\mathrm{t})=\mathrm{a}(\mathrm{t}) \cdot \cos \left(\omega_{\mathrm{v}} \mathrm{t}\right)=\mathrm{a}(\mathrm{t}) \cdot \frac{1}{2} \cdot \mathrm{e}^{\mathrm{j} \omega_{\mathrm{V}} \cdot \mathrm{t}}+\mathrm{a}(\mathrm{t}) \frac{1}{2} \cdot \mathrm{e}^{-\mathrm{j} \omega_{\mathrm{V}} \cdot \mathrm{t}}
$$

A spektrumkép vizsgálatához gondolatban alkalmazzunk egy harmonikus mérőjelet modulálójelként. Az a(t) modulálójel legyen egy egységnyi amplitúdójú $\omega_{\mathrm{m}}$ körfrekvenciájú vizsgálójel:

$$
a(t)=\cos \left(\omega_{m} t\right)=\frac{1}{2} \cdot e^{j \omega_{m} \cdot t}+\frac{1}{2} \cdot e^{-j \omega_{m} \cdot t}
$$

A vizsgálójellel, ha elvégezzük a modulációt, akkor az eredményt az időtartományban a következő összefüggéssel írhatjuk le:

$$
\begin{aligned}
& S_{A M}(t)=a(t) \cdot S_{V}(t)=\left(\frac{1}{2} \cdot e^{j \omega_{m} \cdot t}+\frac{1}{2} \cdot e^{-j \omega_{m} \cdot t}\right) \cdot\left(\frac{1}{2} \cdot e^{j \omega_{V} \cdot t}+\frac{1}{2} \cdot e^{-j \omega_{V} \cdot t}\right)= \\
& =\frac{1}{4} \cdot e^{j\left(\omega_{V}+\omega_{m}\right) \cdot t}+\frac{1}{4} \cdot e^{j\left(\omega_{V}-\omega_{m}\right) \cdot t}+\frac{1}{4} \cdot e^{j\left(-\omega_{V}+\omega_{m}\right) \cdot t}+\frac{1}{4} \cdot e^{j\left(-\omega_{V}-\omega_{m}\right) \cdot t}
\end{aligned}
$$

Most négy összetevőt kapunk eredményként, amely spektrumkép abszolút értéke a következő ábrán figyelhető meg:

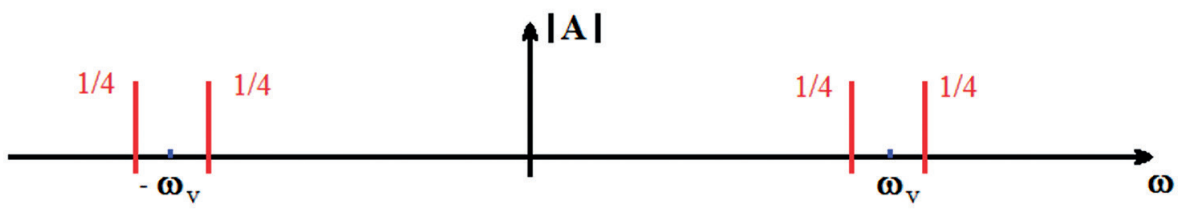

3. ábra

Harmonikus vizsgálójellel végzett modulációs termék spektrumképe [saját szerkesztés]

A spektrumképből eltủnik a modulálatlan vivő komponense, amelynek csak a helyét jelöltem a fenti ábrán, viszont a vivő környezetében $1 / 4$ amplitúdóval előáll a két oldalsáv, vagyis az eredmény egy AM-DSB/SC-jel lesz.

Az előzőekben előállított AM-DSB/SC-jelről a modulálójelet burkoló detektoros demodulátorral $[\mathrm{x}]$ vagy szorzódemodulálással választhatjuk le. Vizsgáljuk meg ez utóbbit úgy, hogy az AM-DSB/SC-jelet megszorozzuk a modulálásnál használt frekvenciájú, egységnyi amplitúdójú, de $\phi$ fázisszög eltérésü jellel.

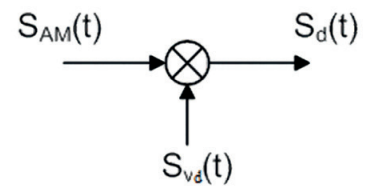

4. ábra

Szorzódemodulátor elvi kialakítása [saját szerkesztés] 
A demodulálást az időtartományban általánosan a következő összefüggésekkel írhatjuk le:

$$
\begin{aligned}
\mathrm{S}_{\mathrm{d}}(\mathrm{t}) & =\mathrm{S}_{\mathrm{AM}}(\mathrm{t}) \cdot \cos \left(\omega_{\mathrm{v}} \mathrm{t}+\varphi\right)=\mathrm{a}(\mathrm{t}) \cos \left(\omega_{\mathrm{v}} \mathrm{t}\right) \cdot \cos \left(\omega_{\mathrm{v}} \mathrm{t}+\varphi\right)= \\
& =\frac{\mathrm{a}(\mathrm{t})}{2} \cdot \cos \varphi+\frac{\mathrm{a}(\mathrm{t})}{2} \cdot \cos \left(2 \omega_{\mathrm{v}} \mathrm{t}+\varphi\right)
\end{aligned}
$$

A fenti összefüggésben a(t) a moduláló jel, a " $\phi$ ” a modulált és a demoduláló vivő jel fáziskülönbsége.

Ugyanezt leírhatjuk forgó vektoros modellel is, amely esetben az előálló spektrális komponensek jól láthatóak:

$$
\begin{aligned}
& S_{d}(t)=S_{A M}(t) \cdot S_{V}(t)= \\
& =\left(\frac{1}{4} \cdot e^{j\left(\omega_{V}+\omega_{m}\right) \cdot t}+\frac{1}{4} \cdot e^{j\left(\omega_{V}-\omega_{m}\right) \cdot t}+\frac{1}{4} \cdot e^{j\left(-\omega_{V}+\omega_{m}\right) \cdot t}+\frac{1}{4} \cdot e^{j\left(-\omega_{V}-\omega_{m}\right) \cdot t}\right) \cdot\left(\frac{1}{2} \cdot e^{j \omega_{V} \cdot t}+\frac{1}{2} \cdot e^{-j \omega_{V} \cdot t}\right)= \\
& =\frac{1}{8} \cdot e^{j\left(2 \omega_{V}+\omega_{m}\right) \cdot t}+\frac{1}{8} \cdot e^{j\left(2 \omega_{V}-\omega_{m}\right) \cdot t}+\frac{1}{8} \cdot e^{j \omega_{m} \cdot t}+\frac{1}{8} \cdot e^{-j \omega_{m} \cdot t}+ \\
& +\frac{1}{8} \cdot e^{j\left(-2 \omega_{V}+\omega_{m}\right) \cdot t}+\frac{1}{8} \cdot e^{j\left(-2 \omega_{V}-\omega_{m}\right) \cdot t}+\frac{1}{8} \cdot e^{j \omega_{m} \cdot t}+\frac{1}{8} \cdot e^{-j \omega_{m} \cdot t}
\end{aligned}
$$

A harmonikus jelekkel leírt tartalomban az $\frac{\mathrm{a}(\mathrm{t})}{2} \cdot \cos \left(2 \omega_{\mathrm{v}} \mathrm{t}+\varphi\right)$ komponens a kétszeres vivő frekvencián előálló modulációs tartalmat jelenti, amely komponens számunkra nem túl hasznos, ezért ezt aluláteresztő szűrővel eltávolítjuk. A megmaradó tartalom az $\frac{\mathrm{a}(\mathrm{t})}{2} \cdot \cos \varphi$ a demodulált jelet jelenti, amely $\phi=0^{\circ}$ esetén $1 / 2$ amplitúdójú az eredeti modulálójel amplitúdójához képest. Abban az esetben, ha a $\phi=90^{\circ}$, akkor a demodulált tartalom amplitúdója nulla értékü, vagyis nem jelenik meg a kimeneten. Ez alapján ha a modulációnál $90^{\circ}$ fáziseltérésű vivőket használunk, akkor ezek ugyanazon a frekvencián is ortogonálisnak, függetlennek tekinthetők, vagyis összegezhetők és majd a vételi oldalon a megfelelő vivő fázishelyzettel demodulálhatók.

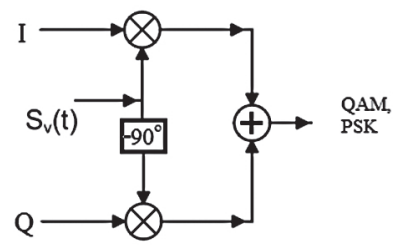

\section{5. ábra}

I-Q-modulátor-kialakítás szorzómodulátorral [saját szerkesztés]

Az I-Q-modulátor kimenetén digitális QAM- vagy PSK-jelet kapunk az I és Q-jelek kialakításától függően. 


\section{I-Q-jelek}

Az „I” (In-Phase) és a „Q” (Quadrature-Phase) jelek egymástól független vivőkön - például egy szinuszos és koszinuszos harmonikus jel, amiben mindkét tag azonos frekvenciájú - továbbíthatók a rendeltetési helyükre.

A következő ábra egy négyállapotú PSK (PSK-4) szimbólumait szemlélteti a komplex (I-Q) síkon:

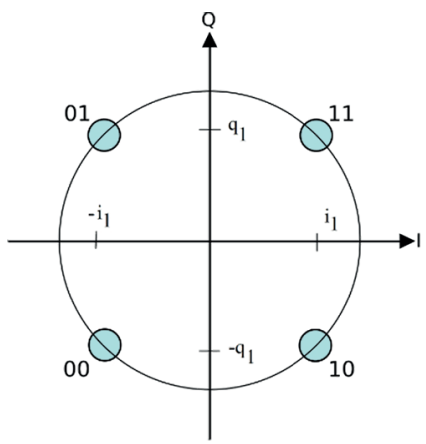

6. ábra

PSK-4 konstellációs ábra [saját szerkesztés]

Az egyes szimbólumok komplex számokkal adhatók meg a síkon, például az '11'-nek kódolt szimbólum helyét az $i_{1}+j^{*} q_{1}$ adja, de nem fontos tudnunk, hogy a vivő jellel kisugárzott jel, vagyis szimbólum egy valós jel. Ennek a kisugárzott jelnek az amplitúdóját gondolatban a szimbólumhoz az origóból húzott vektor hossza, míg fázishelyzetét ugyanezen vektor állásszöge adja. Nulla fokos állásszögnek az „I" tengely pozitív irányába mutató, az „I" tengelyre fekvő vektort tekintjük.

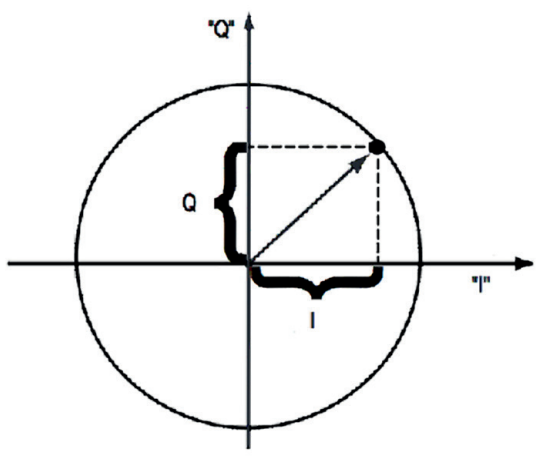

7. ábra

Egy szimbólum I-Q-komponenseinek értelmezése [saját szerkesztés]

A komplex síkon ábrázolt szimbólum két komponenssel adható meg, egy „I" és egy "Q" komponenssel, amelyek szintén valós értékek, például valós feszültségszintek. 
Ugyanakkor ne feledkezzünk meg az eredeti célról, miszerint a drónunk digitális jelfolyamot kíván továbbítani. Ha visszatekintünk a 6. ábrára, ott azt látjuk, hogy az egyes szimbólumok 2 bites számmal kódoltak, vagyis egy szimbólum két bit információt szállít. E példa szerint a szimbólum-előállítás a továbbítandó digitális jelfolyam két bitre tagolt egységei alapján történik.

Magasabb számú szimbólum esetén egy szimbólum több bit információt szállíthat, például PSK-8 esetén 3 bit/szimbólum, QAM-16 esetén 4 bit/szimbólum, QAM-256 esetén 8 bit/szimbólum stb.

\section{I-Q-jelek előállítása}

Első lépésben vizsgáljuk meg az I-Q-jel elöállításának hardverfeltételeit, miszerint egy szimbólum egy „I" és egy „Q” jelszinttel leírható. Mindkét komponens valós fizikai jellemző, például feszültségérték lesz.

Ezeket a feszültségszint-értékeket a digitális jelfeldolgozó processzorhoz illesztett kétcsatornás D/A-konverterrel állíthatjuk elö:

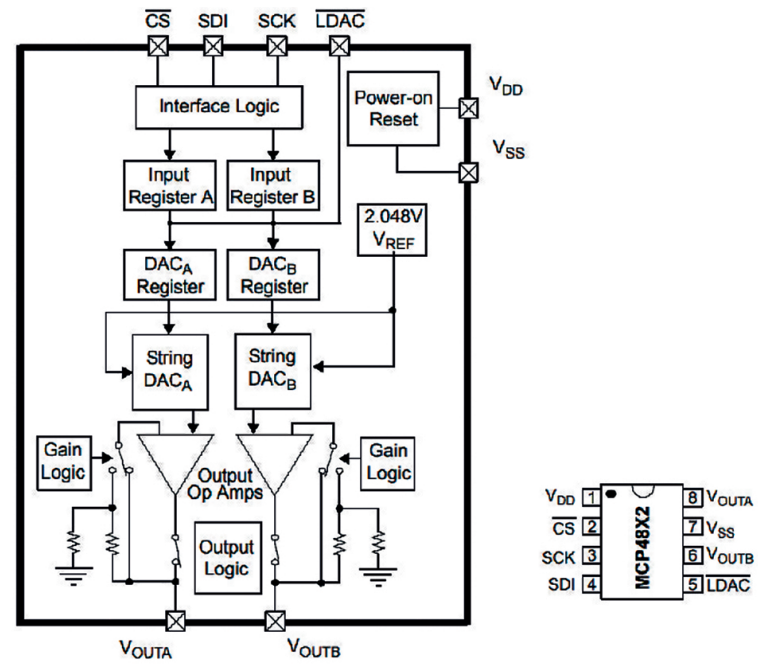

8. ábra

I-Q-komponens gyakorlati elöállitásához használható kétcsatornás D/A-konverter [5]

A 8. ábrán látható chip SPI-interfészen kommunikál, így a jelfeldolgozó processzorhoz illesztése SPI-periférián keresztül valósítható meg. A dsPIC33 jelfeldolgozó kontroller (DSC) család tagjai általában 1-2 ilyen interfésszel rendelkeznek [5]. A kommunikáció tekintetében a jelfeldolgzó processzor lesz a „master”, míg a D/A-konverter a "slave”. Az SPI-kommunikációt az időtartományban a következő ábrán figyelhetjük meg: 


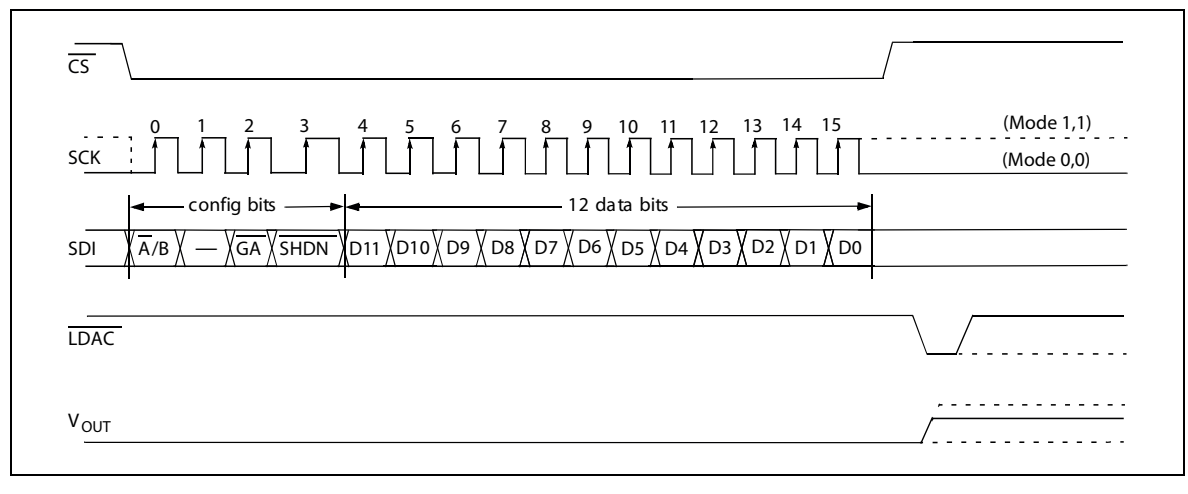

9. ábra

dsPIC33- és D/A-konverter kommunikáció [6]

Az I- és Q-komponenseknek egyidejüleg, vagyis szinkronizáltan kell megjelenniük a D/A-konverter kimenetein, hiszen együttesen írják le a továbbítandó szimbólumot. A D/A-konverter "A", illetve „B" csatornája csak külön-külön, szekvenciálisan írható, de az LDAC-bemenetvezérléssel az „A" és „B" (I-Q) kimenet egyszerre aktiválható.

A következő ábrán egy szimbólumszekvenciára láthatunk példát, amely példában a modulációs eljárásunk PSK-4:

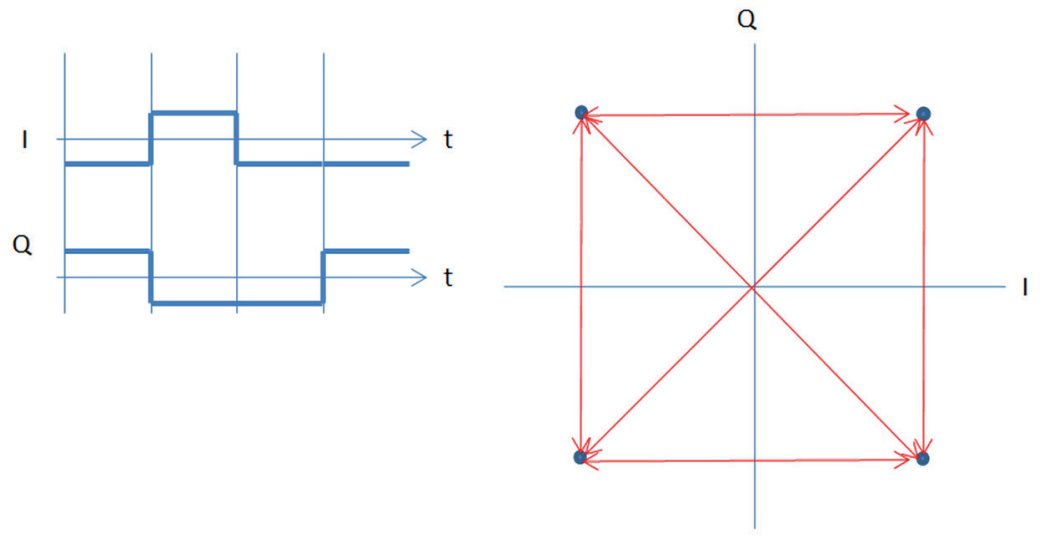

10. ábra

Szimbólumszekvencia-példa négyállapotú PSK-val [saját szerkesztés]

A fenti példa szerint az analóg kimenetek (I-Q-jelek) feszültségszintértékei a kevés állapotszám miatt csak két-két értéket vesznek fel. Nagyobb állapotszám, valamint QAM esetén a D/A kimeneti értékkészlete sokkal kihasználtabb.

A végtelenül gyors szimbólumváltás csak végtelen széles spektrumképü jellel történhet, és a négyszögjelhez hasonlító I-Q-jel spektruma is indokolatlanul nagy sávszélességü. Abban az esetben, ha a vételi oldalon a szimbólumból a mintavétel a szimbólum közepénél történik, akkor az I-Q-jel alapharmonikusa pontosan ugyanazt az információt hordozza, 
mint a 10. ábrán látható példa négyszögjele. A jelformálás úgynevezett emelt koszinuszos (RRC - Root Raised Cosine) szüréssel megtehető, ami a Linear Technology által gyártott LTC1596 chippel kialakítható [7].
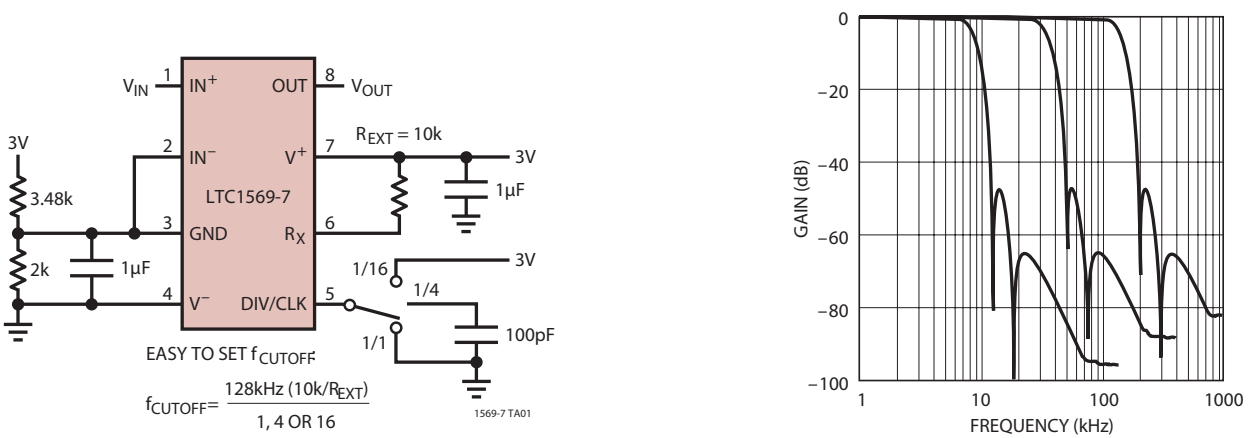

11. ábra

Jelformálószürö-kialakitás és lehetséges frekvenciaátviteli jellemzői [7]

A jelformált „I" vagy „Q" jeleket, ha időtartományban megfigyeljük az úgynevezett „szemábrás" diagrammal, a következőt kapjuk:

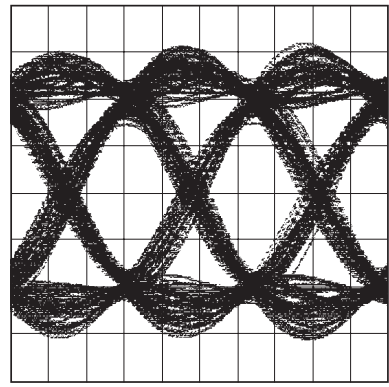

12. ábra

Jelformált I vagy Q-jel szemábrás megjelenitése [7]

A külön külön az I- és Q-csatornán elvégzett szürést viszonylag magas fokszámú analóg szürővel valósítjuk meg, de ennél még nagyobb nehézséget jelent, hogy ezeknek a szürőknek lineáris fázismenetűnek kell lenniük, hiszen az I-Q-csatornák szürésből adódó fáziskülönbség-hibái végzetesek lehetnek, mert az I-Q-síkon az egymáshoz képesti fázishiba a szimbólum helyének elvándorlását eredményezi. Nagy mértékủ szimbólumelvándorlás a szimbólumok közti áthallást (Inter Symbol Interference - ISI) okoz, és ez bithibát eredményez a digitális csatornában.

A jelalakformálás egy lineáris müvelet, ezért az áthelyezhető a digitális oldalra, az A/Dkonverzió elé. Ez esetben viszont a D/A-konverter mintavételi ütemezését sürübbre kell megválasztani, mint a szimbólumidőt. A szürési feladat így direkt struktúrájú, lineáris fázismenetü FIR-szűrővel [9] vagy hullámdigitális tervezési módszerrel kialakított hídszűrővel (LWDF) megvalósítható [8]. Hullámdigitális szürőtervezéssel kialakított DSP-jelfolyamdiagram lineáris körülmények között garantáltan stabil, vagyis gerjedés- és határciklusmentes. Véges 
számábrázolási környezet miatti nemlineáris hatások az esetben nem okoznak problémát, ha a megvalósításkor a passzivitást megtartjuk, például a szorzásmüveleteket követően a kerekítéseket abszolútérték-csonkolással végezzük.

Több fejlesztési munkát és nehezebb átskálázhatóságot jelent az, ha a szimbólummintákat gondolatban előszürjük, ezeket a DSC programmemóriájában letároljuk, és onnan, mint „lookup table"-megoldással a mintavételi ütemezéssel kiolvassuk.

Ez esetben a szürési feladat nem a valós időben történik, hanem a fejlesztési fázisban, így a jelfeldolgozó eszközünkkel megvalósított I-Q-jel előállító modul (symbol mapper) lényegében egy ütemezett táblázatolvasási feladattá egyszerűsödik.

\section{Összegzés}

Jelen cikkben a drónok kommunikációs csatornáihoz alkalmazható digitális I-Q-modulációs megvalósítás elméletét és gyakorlatát kívántam bemutatni. A megvalósítás kis számítási kapacitású, fix pontos számábrázolást alkalmazó digitális jelfeldolgozó processzorral is történhet. Az algoritmusokat dsPIC33FJ és E sorozatú DSC-n teszteltem, jelformáláshoz mind a direkt struktúrájú, mind pedig a hullámdigitális eljárásokat vegyesen alkalmaztam. Jelen cikkben elsősorban az elméleti alapok összegzését és a hardver kialakítását mutattam be.

\section{Hivatkozások}

[1] M. Palik, „100 éves a magyar repülésirányítás,” in Repüléstudományi Szemelvények, B. Békési és L. Szilvássy szerk. Szolnok, Magyarország: Nemzeti Közszolgálati Egyetem Katonai Repülő Intézet, 2016, pp. 205-231.

[2] G. Major, M. Palik és B. Kiss, „Migration from a Bird's Eye View," Repüléstudományi Közlemények, 29. évf. 3. sz. pp. 189-202. 14 p. 2017.

[3] I. Makkay, „Ütközések elkerülése a kisgépes és a pilóta nélküli repülésben,” Repüléstudományi Közlemények, 29. évf. 1 sz. pp. 59-66. 8 p. 2017.

[4] L. Ványa, „Pilóta nélküli repülő eszközök elektronikai hadviselési alkalmazása szakértői rendszer támogatásával," Repüléstudományi Közlemények, Klnsz. 1. pp. 213-220. 8 p. 2001.

[5] dsPIC33E Family Data Sheet (DS70616G), [Online]. Elérhető: http://ww1.microchip.com/ downloads/en/devicedoc/70616g.pdf (Letöltve: 2020. 02. 18.)

[6] MCP4822 Data Sheet, [Online]. Elérhető: http://ww1.microchip.com/downloads/en/ devicedoc/20002249b.pdf (Letöltve: 2020. 02. 18.)

[7] Analog Devices, "LTC1569-7 Data Sheet," Analog Devices, [Online]. Elérhető: www.analog. com/media/en/technical-documentation/data-sheets/15697fs.pdf (Letöltve: 2020. 02. 18.)

[8] L. Gazsi, "Explicit Formulas for Lattice Wave Digital Filters," IEEE Transactions on Circuits and Systems, vol. 32, no. 1. pp. 68-88. January 1985. DOI: https://doi.org/10.1109/ tcs.1985.1085595

[9] T. Wührl, DSP algoritmusok. Budapest: Óbudai Egyetem-KVK-2116, 2014.

[10] T. Wührl, Hullámdigitális jelfeldolgozás alapjai. Budapest: Óbudai Egyetem-KVK-2073, 2010. 


\section{DRONE COMMUNICATION EFFICIENT REALISATION OF DIGITAL I-Q MODULATION WITH DIGITAL SIGNAL CONTROLLER}

Drones are used in many areas. Almost every application requires drones to receive or send information to another drone or to the ground segment. On the analogue transmission channel, information described by digital signals can be transmitted by digital modulation techniques.

In this article, I present an effective multilevel digital modulator that can be implemented with a low-cost signal controller using fixed-point representations of numbers. The presented DSP algorithm produces an analogue $I-Q$ output signal that can be converted to an $R F$ radio signal by an analogue AM-DSB/SC method with orthogonal carriers.

Keywords: drone, communication, I-Q-modulator, DSP

Dr. habil. Wührl Tibor PhD

egyetemi docens

Óbudai Egyetem, Kandó Kálmán Villamosmérnöki Kar, Híradástechnika Intézet

wuhrl.tibor@kvk.uni-obuda.hu

https://orcid.org/0000-0002-7522-3511
Dr. hab. Tibor Wührl, PhD

Associate Professor

Óbuda University, Telecommunication department

wuhrl.tibor@kvk.uni-obuda.hu

https://orcid.org/0000-0002-7522-3511

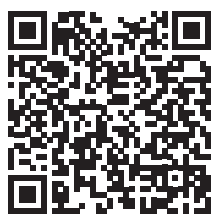

